\title{
\#The Brilliant Billion that gave the planet animal evolution
}

\author{
INDRANI MUKHERJEE ${ }^{1}$, ROSS CORKREY ${ }^{3}$ AND ROSS \\ $\mathrm{LARGE}^{2}$ \\ ${ }^{1}[$ Centre for Ore Deposit and Earth Sciences (CODES), \\ University of Tasmania, Hobart, Australia; \\ indrani.mukherjee@utas.edu.au] \\ ${ }^{2}$ Centre for Ore Deposit and Earth Sciences (CODES), \\ University of Tasmania, Hobart, Australia; \\ ross.large@utas.edu.au] \\ ${ }^{3}$ [Tasmanian Institute of Agriculture, University of Tasmania, \\ Hobart, Australia; stephen.corkrey@utas.edu.au]
}

Conventional credence in the importance of $\mathrm{pO}_{2}$ on life, the appearance of the first metazoans in the rock record at $800 \mathrm{Ma}$, and the general human fascination with macroscopic fossils of the Ediacaran, are some of the reasons why the Middle Earth is undeservedly referred to as the "Boring Billion”. Despite several lines of evidence pointing toward critical milestones in biological evolution (eukaryogenesis, multicellularity, origin of sex, motility) including the origins of metazoans, the period continues to be descibed as one with futile geostability.

This paper aims to discuss the prerequisites for multicellular animals from their unicellular counterparts and highlight the role of environmental cues during the "Brilliant Billion" alongside biological innovations (cell adhesion, signalling and transcriptional regulation). Our research compares the benefits and pitfalls of relating geological trends with the evoutionary history of animals. For instance, the current models for the unicellular ancestors of metazoans are limited to a few species only. Also, the appearance of metazoans or "explosion" of lifeforms in the rock record prompts one to accept the possibility of prior evolutionary innovations. This study underscores abiotic influences on the evolution of life and compares recent geochemical trends to posit a range of possible scenarios for animal evolution. 